\title{
CHORE BASED LANGUAGE TEACHING
}

\section{B. RADHA ${ }^{1} \&$ CHANDRAMOLI. M $^{2}$}

${ }^{l}$ English Division, Department of $S \& H$, Chirala Engineering College, Chirala-, India \& Research scholar Department of English, in K. L University, Vaddeswaram, Guntur, India

${ }^{2}$ Asstistant. Professor Department of English, K. L University, Vaddeswaram, Guntur, India

\begin{abstract}
Chore Based Language Teaching to secondary school learners is utmost provocation. As a teacher, you have to acknowledge the learner's attention, parents care and teacher's involvement. Teachers have to foster research based methods of English language teaching since scientifically based knowledge has been flourishing in serving language learners develop learning that is fulfilling level of linguistics, dexterity and mastery of chore based learning. Additionally, teachers are supposed to reform their classes as per their learners a variety of necessities. Parents care and students attention differ and what mechanism works with one learner does not fundamentally work for another. This study follows the qualitative research method in view of the fact that it is a research made by survey. The data is collected of the participants' pre and post tests that were evaluated using the articles, tenses and prepositions. The participants are the learners of Grade 9 and 10 from different schools. The results proved that following the designed chore based language teaching has improved the learner's academics and therefore, the researchers propose for the use of CBLT to be accepted. KEYWORDS: Acknowledge, CBLT \& Fundamentally
\end{abstract}

Received: Oct 12, 2017; Accepted: Nov 02, 2017; Published: Nov 25, 2017; Paper Id.: IJELDEC20176

\section{INTRODUCTION}

Chore Based Language Teaching includes tentative knowledge and humanistic learning. Nunan (2017) (a). CBLT provides the opportunity for natural learning, within the classroom context [b]. A chore is a piece of classroom work that involves learners in comprehending, manipulating, producing or interacting in the target language while their attention is focused on mobilizing their grammatical knowledge in order to express meaning and in which the intention is to convey meaning rather than to manipulate form(c). As per Murphy it is also necessary to consider the ways in which learners interact with chores within the classroom environment and this small-scale study investigates the relationship between chores and learners (d). CBLT has been propagated by the national government as the most favored approach to second and foreign language teaching (e)(f). In spite of uncertain wrangling on what it strictly is(Bailey 2006,pp.213-222), for English as a Second Language / English as Foreign Language (ESOL/EFL) background on efficient teacher can enormously be reenacted as the one who administers the students the objectives. In other words the one who produces a group of go-getter learners (Ariakn, Taser \& Sarac- Slizer 2001) (g). Teachers are supposed to have the aspects and parameters, to organize trenchant in the classes. Actually teaching is a profession for a teacher incorporating a number of roles as a facilitator. (Spratt, Pulverness \& Williams (2005) 145.(h).

In his ground-shaking book, Kumaravadivelu $(2003,2008)$ reveals the teachers as facilitator. Since they are anticipated to play various roles both in and outside the instruction room.(i)(j). As Mourshed, Chijioke, 
\& Barbar, (2010) said the success of any educational institution is the TEACHER.(k), As per the adaptation of Arndt, Harvey \& Nuttall, 2000,Van Lier, (2001, pp.10-15) the teacher is an crucial in many aspects. (1). Reynolds et al., 2014 stated that some schools move effectively teach reading, mathematics and sciences than other subjects (m).

The importance of a cognitively stimulating learning environment in school to support students' cognitive development as discovered by Karin Guill, Oliver Ludtke, Olaf Koller (2017)(n). Mustafa Er, Serlam Ulgu, Irfan Sari (2013) states Teaching as a line of work for Language Teachers.(o). The purpose of this paper is to prove that, CBLT has improved the learner's academics.

\section{Opinion of the Study}

The principle of this study is to probe how the teachers' involvement, students' attention and parents' care are interdependent which directly improves the learners in their academics and making them vastly skillful in English language learning. Their betterment was developed by the exercise of CBLT, which facilitated them to be successful in a 6 day programmed.

\section{Research Question}

This study endeavors at coming back with the following question.

Does the application of CBLT sketched out for academics enrich learner's performance.

\section{LITERATURE REVIEW}

Teaching is one of the most multifaceted activities involving grammar. As per the educators who have always acknowledged learning easier said than done to adapt access, analyze and score. Even now-a-days, learning is still heeded as a challenging Chore including a ample collection of skills and sub-skills. Learners generally cannot be gregarious attuned of all the learning methods engaged when learning English as a language. Therefore, the teachers have to carefully plan the teaching strategies where the students can consciously pay attention while listening and working on their texts which also include grammar contexts like articles, tenses and prepositions.

When the learners do not have adequate parents' care towards the learning, it is the teachers' responsibility to accommodate them with sufficient spells to make them learn using their language classes. The instruction strategies to be used depend mainly on the information or skill that is being taught, and it may also be influenced by the learning style, aptitude skills and enthusiasm of the students. The instruction strategies involve:

- Lecture method.

- The discussion method.

- The demonstration method.

Since learning is a teaching is a critical process, the teachers have to continually modify their attitudes and adjust their methods as per requirement demands.

It is ponderous to comfort learners promote their attention in academics using English language as a channel. Teachers ought to work at developing their learner's attention, authoring them appreciates that language learning can be strongly acquired when ensuring thoroughgoing strategies. 
It is important to note that many learners in Andhra Pradesh schools neither have literate parents nor enough parental care. A approach for doing so is teaching learners to follow the oral method which can bend them into extensible learners. Through interactive method of teaching, teachers can develop invention strategies to encourage their learners in attractive competent learners. From this perspective, the CBLT template has been developed for the high schools learners.

\section{TECHNIQUE}

This study aims at developing the importance of teacher's involvement, learner's attention and parents' care in learning. The teachers where the learners do not have proper parent care are to be identified and plan to improve them separately.

\section{Design}

This revise is an achievement that where one is heeded at supporting the researcher in remodeling and promoting their instruction methods. It follows the qualitative method of analysis data. The Common Core State Standards Writing Rubric has been used to take account of the learning.

\section{Participants}

The learners associated in this study are a means sample. They are learners of Grade 9 and 10. The learners are 15 in each grade, which is a high school English language class whose learners are from rural and urban areas with and without enough parental care towards their child learning.

Table I: Participants

\begin{tabular}{|l|l|l|l|}
\hline Particulars & Grade 9 & Grade 10 & Total \\
\hline Learners & 15 & 15 & 30 \\
\hline
\end{tabular}

Table 2: Participants

\begin{tabular}{|c|c|c|c|}
\hline Particulars & Grade 9 & Grade 10 & Total \\
\hline Learners (Rural Area) & 30 & 30 & 60 \\
\hline Learners (Urban Area) & 30 & 30 & 60 \\
\hline
\end{tabular}

Table 3: Participants

\begin{tabular}{|l|c|c|c|}
\hline \multicolumn{1}{|c|}{ Particulars } & Grade 9 & Grade 10 & Total \\
\hline Learners(Rural \& Urban ) & 60 & 60 & 120 \\
\hline Learners for academic year & 5000 & 5000 & 10000 \\
\hline
\end{tabular}

\section{Instrument}

In this research, pre \& post tests in learning were monitored. A template stand in one's shoes articles, tenses and prepositions in grammar was taken in 12 classes was given in which the learners had to respond to by giving the test. The first diagnostic pre-session test was conducted before the teaching of grammar and the second test was conducted after the grammar was taught for 12 classes. The tests were figured out resulting the Common Core State Standards devised the English Professional Learning Council [EPLG].

\section{Process of Data Collection}

The 2017-18 academic year for school started on June $15^{\text {th }} 2017$. The participants have been attending to their classes since then. The first test was administered in the beginning of the grammar revision and the second test after the 
revision of 12 classes in a period of 6 days. The tests were related to articles, tenses and prepositions with 3 , 4 and 3 sentences respective fully. These tests were designed as pre \& post tests.

\section{FINDING}

After every test, marks were formulated for data collection. Later tables were constructed on Excel and means of the pre $\&$ post tests were calculated.

Table 4

School 1: 24\%

\begin{tabular}{|l|c|c|c|}
\hline & $\begin{array}{c}\text { Pre-Test } \\
\text { Marks }\end{array}$ & Post Test Marks & improvement \\
\hline Grade 9 & 5 & 6.6 & 1.6 \\
\hline Grade 10 & 4.1 & 7.3 & 3.2 \\
\hline Grade 9 \&10 Mean & 4.55 & 6.9 & 2.4 \\
\hline
\end{tabular}

School 2: $22 \%$

\begin{tabular}{|ll|c|c|c|}
\hline \multicolumn{2}{|c|}{ Class } & $\begin{array}{c}\text { Pre-Test } \\
\text { Marks }\end{array}$ & $\begin{array}{c}\text { Post Test } \\
\text { Marks }\end{array}$ & improvement \\
\hline Grade 9 & & 2.6 & 5.1 & 2.5 \\
\hline Grade 10 & & 4.6 & 6.6 & 2.0 \\
\hline $\begin{array}{l}\text { Grade } 9 \quad \& 10 \\
\text { Mean }\end{array}$ & 3.6 & 5.8 & 2.2 \\
\hline
\end{tabular}

School 3: $21 \%$

\begin{tabular}{|l|l|l|l|}
\hline \multicolumn{1}{|c|}{ Class } & \multicolumn{1}{|c|}{$\begin{array}{c}\text { Pre-Test } \\
\text { Marks }\end{array}$} & $\begin{array}{c}\text { Post } \\
\text { Test } \\
\text { Marks }\end{array}$ & improvement \\
\hline Grade 9 & 4.9 & 7.3 & 2.4 \\
\hline Grade 10 & 6.1 & 7.9 & 1.8 \\
\hline Grade 9 \&10 Mean & 5.5 & 7.6 & 2.1 \\
\hline
\end{tabular}

School 4: 18\%

\begin{tabular}{|l|c|c|c|}
\hline \multicolumn{1}{|c|}{ Class } & $\begin{array}{c}\text { Pre-Test } \\
\text { Marks }\end{array}$ & $\begin{array}{c}\text { Post Test } \\
\text { Marks }\end{array}$ & improvement \\
\hline Grade 9 & 3.8 & 6.2 & 2.4 \\
\hline Grade 10 & 4.3 & 5.6 & 1.3 \\
\hline Grade 9 \&10 Mean & 4.1 & 5.9 & 1.8 \\
\hline
\end{tabular}

The template's "success" in improving the learners' academics/grammar learning skills attention was found a change up to $20 \%$ in increase on an average.

Table 5: Difference in Parents Care: 3\%

\begin{tabular}{|c|l|l|l|}
\hline Particulars & Grade 9 & Grade 10 & Improvement \\
\hline Participants from Rural Area & 3.9 & 5.9 & 2.0 \\
\hline Participants from Urban Area & 5.0 & 7.3 & 2.3 \\
\hline
\end{tabular}

The template's success in parents care in improving the learner's academics also reflected in learner's performance.

Improvement comparison between Urban and Rural: 

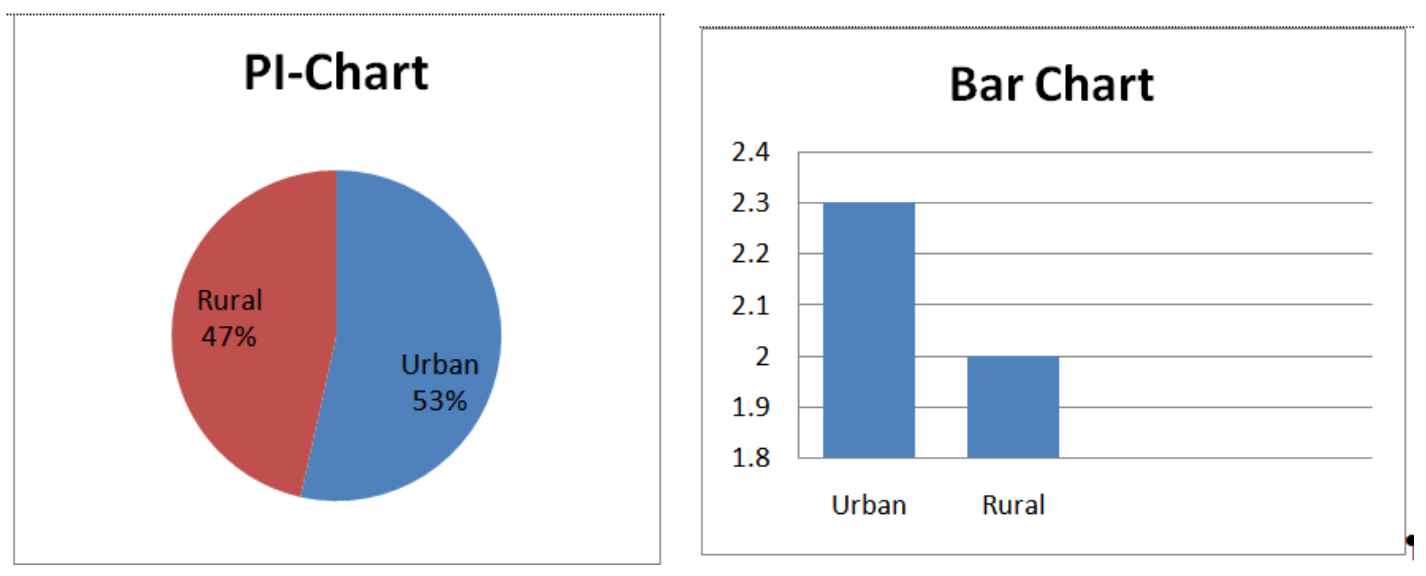

Table 6: If applied For the Whole State is $21 \%$

\begin{tabular}{|l|l|l|l|}
\hline \multicolumn{1}{|c|}{ Particulars } & $\begin{array}{c}\text { Pre test } \\
\text { marks }\end{array}$ & $\begin{array}{c}\text { Post test } \\
\text { Marks }\end{array}$ & Improvement \\
\hline 120 participants & 4.45 & 6.6 & 2.15 \\
\hline Whole state & 4.45 & 6.6 & 2.15 \\
\hline
\end{tabular}

The template's success in improving the learner's academics reflected that teachers involvement, learner's attention and parents' care reflects in learner's performance.

\section{LIMITATIONS}

Three major limitations are present in this current study:

First, the learners are a convenient sample chosen by the researcher. Secondly, they are different types of achievers in English language learning. Finally, though the class consisted of 30-40 students each only 15 students per class were considered.

\section{INFERENCE AND GUIDANCE}

The learner's academics enhanced in a very short period i.e., 12 classes in 6 days. The researchers speak well of providing the means of the CBLT since, it negotiated the participants with an average of $20 \%$ in individual improvements and also, developed impudence in learning. Besides, it elaborated their achievement in English language. This template showed show case in a very short span, there up on if it can be implemented for long time the learners may have more outcome based on this kind CBLT input.

\section{REFERENCES}

1. David Nunan (2017), Chore Based Language Teaching Chapter 14, Teaching English as a Second or Foreign Language.

2. Chore Based Language Teaching; what every EFL teacher should do-by Murat Hismanoglu and Sibel Hismanoglu in Procedia Social \& Behavioral Sciences 15 (2011) 46-52.

3. Nunan (2004), Chore Based Language Teaching: Cambridge: Cambridge University Press pp.12-18.

4. Murphy.J. (2003): Chore Based Learning: The interaction between Chores and learners, ELT Journal, 57(4), 32-360.

5. K.Van Den Branden, (2006), Chore Based Language Teaching: from theory to practice. Cambridge: Cambridge University Press.

6. K.Van Den Branden-handbook of English Language Teaching 2016. 
7. Bailey, K.M. (2006), Language Teacher supervision: A Case based approach. New York, NY: Cambridge University Press.

8. Arikan. A., Taser, D., \& Suzer, H.S.S, (2008). The effective foreign language teacher from the perspectives of Turkish preparatory school students. Education \& Science, 33, 42-51.

9. Sprott, M., Pulverness, A., \& Williams, M. (2005)pp.145. The TKT (Teaching Knowledge Test) Course Casmbridge: Cambridge University Press.

10. Kumaravadivelu, B. (2004)pp.5-17. Beyond methods: Macrostrategies for language teaching. New Haven and London: Yale University Press.

11. Kumaravadivelu, B. (2008): Understanding Second Language Teaching from method to post method New Jersy: Lawrence Erlbaum Associates.

12. Morshed, M., Chikople, C., \& Barber, M., (2010). How the World's best improved systems are getting better Mckinsey \& Company. Unpublished report, Retrieved on April 11, 2012 from http://makinseyonsociety.com/ how-the world's -most improved - school-systems - keep - getting - better/.

13. Var Lier, I., (2001): Language awareness In Carter, R., \& Nunan, D., (Eds), The Cambridge Guide to Teaching English to Speakers of other Languages: (pp.160-165), Cambridge: Cambridge University Press.

14. Mustafa Er, Sersan Ulgu, IRfan Sari: Procedia Social \& Behavioral Sciences 70 (2013) pp.41-51.

15. Reynolds, D., Sammons, P., De Franca, B., Van Damme, J., Townsend, I., Teddle, C, et.al. (2014): Educational effectiveness Research (EER): A state - of - the - art review School Effectiveness \& Social Improvement 25(2), pp.197-230.

16. Karin Guill, Oliver Ludtke, Olaf Koller: Learning and Instruction (2017): Academic Trackling is related to gains in students' intelligence over for years: Evidence from a propensity Score matching study: ELSVIER 47 (2017) pp.43-52. 